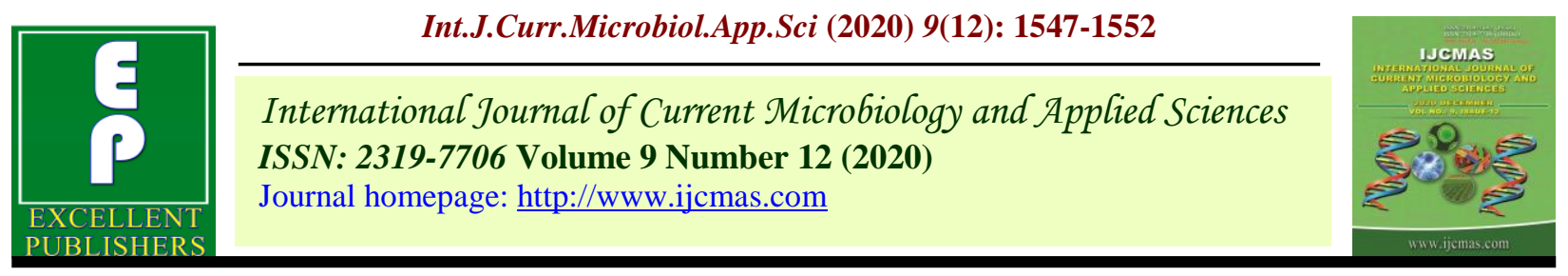

Original Research Article

https://doi.org/10.20546/ijcmas.2020.912.183

\title{
Genetic Analysis for Quantitative Traits in Cucumber [Cucumis sativus (L.)]
}

\author{
M. I. Manivannan ${ }^{1 *}$, R. Arulmozhiyan ${ }^{2}$ and R. Suresh ${ }^{3}$ \\ ${ }^{1}$ Horticultural Research Station, Kodaikanal, India \\ ${ }^{2}$ Department of Horticulture, Agricultural College \& Research Institute Killikulam, India \\ ${ }^{3}$ Department of Spices and Plantation Crops, HC\&RI, Coimbatore, India \\ *Corresponding author
}

\begin{abstract}
A B S T R A C T
Keywords

Genetic variability,

Character

association,

Cucumber,

heritability, Genetic

advance as percent

of mean

Article Info

Accepted:

12 November 2020

Available Online:

10 December 2020

The present study on variability, heritability, genetic gains, correlation coefficients and path coefficients in twenty four diverse cucumber genotypes was carried out for fruit yield and yield attributing traits. The genotypes exhibited significant differences for all the traits under study. A wide range of variability along with estimates of PCV and GCV was observed for number of primary branches, node at which first female flower appear, number of fruits per plant, yield per vine and yield per hectare. High heritability and high expected genetic gain were observed for node at which first female flower appear, number of primary branches, number of fruits per plant and yield per vine indicate that these characters had additive gene effect and therefore, these are more reliable for effective selection. Correlation coefficient and path coefficient revealed that fruit yield could be successfully improved upon by making selection for greater number of primary branches per plant, node at which first female flower appeared and number of fruits per plant.
\end{abstract}

\section{Introduction}

Cucumber (Cucumis sativus L.) is considered as $4^{\text {th }}$ most important vegetable crop after tomato, cabbage and onion (Tatlioglu, 17), which is thought to be indigenous to India. It is the most important salad crop of the family cucurbitaceae. It is a rich source of vitamin $\mathrm{B}$ and $\mathrm{C}$, carbohydrates, $\mathrm{Ca}$ and $\mathrm{P}$ (Yawalkar, 1985).A wide range of genetic variability is available in cucumber, providing good scope for improvement in yield and other character of cucumber through selection. To initiate any effective selection programme, the information on the nature and the magnitude of variability presents in genetic stocks, heritability and genetic advance is of considerable importance for a breeder. Correlation studies between fruit weight and its components and their relative contribution to yield will be of great value in planning and evaluating breeding programme for salad cucumber. Although, correlation coefficient indicates the nature of association among the 
traits, path analysis splits the correlation coefficients into measures of direct and indirect effects, thus providing an understanding on direct and indirect contribution of each character towards yield. Therefore, an attempt was made in the present investigation to estimate the extent of variability, heritability, genetic advance, correlation and path analysis by utilizing 24 divergent cucumber lines.

\section{Materials and Methods}

The present experiment was carried out at Department of Horticulture, Agricultural College \& Research Institute, TNAU, Killikulam during rabi season of2018. Twenty four diverse genotypes (lines), viz., KCS 1, KCS 2, KCS 3, KCS 4, KCS 5, KCS 6, KCS 7, KCS 8, KCS 9, KCS 10, KCS 11, KCS 12, KCS 13, KCS 14, KCS 15, KCS 16, KCS 17, KCS 18, KCS 19, KCS 20, KCS 21, KCS 22, KCS 23 and KCS 24 collected from Assam Agricultural University, Jorhat and Kerala Agricultural University, Vellayani and also through intensive surveys made at Thoothukudi, Virudhunagar, Tenkasi and Tirunelveli districts of Tamil Nadu in places like Radhapuram, Sattur, Sivakasi, Kallipatti, Surandai, Mecheri, Vembakottai, Pavoorchatram, Chinakollanpatti, Periyakollanpatti, Erukanpatti, Yelayirampannai, Aalampalayam, Thaiyalpatti, Tenkasi, Nanguneri, Kuruvikulam, Aalantha, Manathi, Villikury and Karungulam, respectively were grown in randomized block design with three replications at a spacing of $75 \times 60 \mathrm{~cm}$ accommodating 10 plants in a replication. Recommended cultural practices were adopted for proper growth and stand of the crop. Observations were recorded on five randomly selected plants in each replication for ten quantitative characters viz.,plant height (cm), number of primary branches per vine, days to $50 \%$ flowering, node at which first female flower appeared, fruit length $(\mathrm{cm})$, fruit circumference $(\mathrm{cm})$, number of fruits per plant, fruit weight $(\mathrm{g})$, yield per plant $(\mathrm{kg})$ and yield per hectare $(\mathrm{t})$. The data were subjected to analysis of variance as per procedure described by Panse and Sukhatme (12). The coefficient of phenotypic and genotypic variation were calculated according to Burton and DeVane (2), heritability, genetic advance and genetic gain were calculated according to the formulae of Johnson et al., (6). The correlation coefficients were undertaken as per procedure suggested by Al-Jibouri et al., (1) along with path coefficient analysis by Deweyand Lu (4).

\section{Results and Discussion}

The mean of sum square was highly significant for all traits indicating the presence of wide range of variability in the genotypes (Table 1). The magnitude of phenotypic coefficient of variation (PCV) was greater than the corresponding genotypic coefficient of variation (GCV) for all the characters(Table 2). High GCV and PCV, respectively were recorded for number of primary branches, node at which first female flower appear, number of fruits per plant, yield per vine and yield per hectare. This reflects greater genetic variability among genotypes for these characters for making further improvement by selection. Joshi et al., also reported similar results in cucumber. Phenotypic and genotypic coefficients of variation were quite low for fruit weight and fruit length. Rest of characters recorded moderate coefficient of variation. The information obtained show that the estimates of PCV were higher than GCV. However, the differences between phenotypic and genotypic coefficient of variation were quite low. The characters studied were influenced by environment to lesser extent, thus the selection based on phenotypic performance will be reliable. 
Table.1 Mean performance of the various accessions for different quantitative characters in cucumber

\begin{tabular}{|c|c|c|c|c|c|c|c|c|c|c|}
\hline Genotypes & $\begin{array}{c}\text { Vine } \\
\text { length } \\
(\mathrm{cm})\end{array}$ & $\begin{array}{l}\text { Number } \\
\text { of } \\
\text { primary } \\
\text { branches }\end{array}$ & $\begin{array}{c}\text { Days to } \\
\text { first } \\
\text { female } \\
\text { flowering }\end{array}$ & $\begin{array}{c}\text { Node at } \\
\text { which } \\
\text { first } \\
\text { female } \\
\text { flower } \\
\text { appear }\end{array}$ & $\begin{array}{c}\text { Fruit } \\
\text { length } \\
(\mathrm{cm})\end{array}$ & $\begin{array}{c}\text { Fruit } \\
\text { Circum } \\
\text { ference } \\
\text { (cm) }\end{array}$ & $\begin{array}{c}\text { Number } \\
\text { of } \\
\text { fruits } \\
\text { per } \\
\text { plant }\end{array}$ & $\begin{array}{c}\text { Fruit } \\
\text { weight } \\
\text { (g) }\end{array}$ & $\begin{array}{c}\text { Yield } \\
\text { per } \\
\text { vine } \\
\text { (kg) }\end{array}$ & $\begin{array}{l}\text { Yield } \\
\text { (t/ha) }\end{array}$ \\
\hline KCS 1 & 260.16 & 3.33 & 32.33 & 11.33 & 17.59 & 11.33 & 11.00 & 152.75 & 1.68 & 7.46 \\
\hline KCS 2 & 226.16 & 5.00 & 41.00 & 11.00 & 19.44 & 11.30 & 10.75 & 164.36 & 1.77 & 7.85 \\
\hline KCS 3 & 232.16 & 3.66 & 34.00 & 12.00 & 20.10 & 10.70 & 10.00 & 170.00 & 1.70 & 7.56 \\
\hline KCS 4 & 280.66 & 5.00 & 55.66 & 13.33 & 20.32 & 13.83 & 8.75 & 192.58 & 1.69 & 7.49 \\
\hline KCS 5 & 290.16 & 3.66 & 40.00 & 15.66 & 21.94 & 14.43 & 7.25 & 202.00 & 1.46 & 6.51 \\
\hline KCS 6 & 191.50 & 4.33 & 29.33 & 11.00 & 17.60 & 12.10 & 11.00 & 168.16 & 1.85 & 8.22 \\
\hline KCS 7 & 200.16 & 6.66 & 27.00 & 7.00 & 18.77 & 10.67 & 12.38 & 175.68 & 2.18 & 9.67 \\
\hline KCS 8 & 239.66 & 4.00 & 38.00 & 8.00 & 20.38 & 11.21 & 10.75 & 177.00 & 1.90 & 8.46 \\
\hline KCS 9 & 257.83 & 4.66 & 39.00 & 9.00 & 20.60 & 11.70 & 12.00 & 180.50 & 2.17 & 9.63 \\
\hline KCS 10 & 195.50 & 4.66 & 43.33 & 13.00 & 22.50 & 12.20 & 9.50 & 194.40 & 1.85 & 8.21 \\
\hline KCS 11 & 201.50 & 5.45 & 34.33 & 10.66 & 19.33 & 9.67 & 9.75 & 178.00 & 1.74 & 7.72 \\
\hline KCS 12 & 280.33 & 4.00 & 36.33 & 11.33 & 19.21 & 8.32 & 9.50 & 140.44 & 1.33 & 5.93 \\
\hline KCS 13 & 200.33 & 4.66 & 40.00 & 13.00 & 16.50 & 11.00 & 8.00 & 146.22 & 1.17 & 5.20 \\
\hline KCS 14 & 178.66 & 4.00 & 39.66 & 11.00 & 23.40 & 12.10 & 11.00 & 185.52 & 2.04 & 9.07 \\
\hline KCS 15 & 218.83 & 3.66 & 39.00 & 12.33 & 22.38 & 12.27 & 10.00 & 184.99 & 1.85 & 8.22 \\
\hline KCS 16 & 206.33 & 4.33 & 39.33 & 13.00 & 22.50 & 9.40 & 9.75 & 174.00 & 1.70 & 7.54 \\
\hline KCS 17 & 207.83 & 4.66 & 37.00 & 14.66 & 22.40 & 11.51 & 7.25 & 184.68 & 1.34 & 5.95 \\
\hline KCS 18 & 235.33 & 5.00 & 29.66 & 12.66 & 19.44 & 11.86 & 10.00 & 179.62 & 1.80 & 7.98 \\
\hline KCS 19 & 276.83 & 3.66 & 29.66 & 12.33 & 20.05 & 12.31 & 10.00 & 184.78 & 1.85 & 8.21 \\
\hline KCS 20 & 238.66 & 3.33 & 38.00 & 8.33 & 18.50 & 10.10 & 12.50 & 151.32 & 1.89 & 8.41 \\
\hline KCS 21 & 293.83 & 2.66 & 38.33 & 20.00 & 19.70 & 11.24 & 5.75 & 179.26 & 1.03 & 4.58 \\
\hline KCS 22 & 212.16 & 2.00 & 26.66 & 17.33 & 21.88 & 10.67 & 7.25 & 182.50 & 1.32 & 5.88 \\
\hline KCS 23 & 185.83 & 3.33 & 35.00 & 14.66 & 22.58 & 11.65 & 6.50 & 181.29 & 1.18 & 5.23 \\
\hline KCS 24 & 179.33 & 3.38 & 38.33 & 20.66 & 23.55 & 12.00 & 5.00 & 185.70 & 0.93 & 4.13 \\
\hline Mean & 228.74 & 4.13 & 36.71 & 12.64 & 20.44 & 11.40 & 9.40 & 175.66 & 1.64 & 7.30 \\
\hline SE d & 3.95 & 0.06 & 0.51 & 0.16 & 0.28 & 0.12 & 0.13 & 2.60 & 0.02 & 0.11 \\
\hline $\begin{array}{l}\text { CD } \\
(p=0.05 \%)\end{array}$ & 11.24 & 0.17 & 1.46 & 0.45 & 0.80 & 0.35 & 0.38 & 7.40 & 0.06 & 0.30 \\
\hline $\mathrm{CV}(\%)$ & 2.99 & 2.57 & 2.42 & 2.19 & 2.40 & 1.89 & 2.46 & 2.57 & 2.41 & 2.52 \\
\hline
\end{tabular}


Table. 2 Coefficient of variation, heritability, genetic advance and genetic advance as \% of mean for different quantitative traits

\begin{tabular}{|l|c|c|c|c|}
\hline \multirow{2}{*}{\multicolumn{1}{|c|}{ Genetic Parameters/Traits }} & \multicolumn{2}{c|}{ Co efficient of Variance } & \multirow{2}{*}{ H $\left.^{\mathbf{2}} \mathbf{\%}\right)$} & \multirow{2}{*}{ GAM } \\
\cline { 1 - 4 } & PCV (\%) & GCV (\%) & & \\
\hline Vine length (cm) & 16.17 & 15.89 & 96.57 & 32.17 \\
\hline Number of primary branches & 23.63 & 23.49 & 98.81 & 48.10 \\
\hline Days to first female flowering & 16.80 & 16.62 & 97.92 & 33.88 \\
\hline Node at which first female flower appear & 26.66 & 26.57 & 99.33 & 54.55 \\
\hline Fruit length (cm) & 9.73 & 9.43 & 93.93 & 18.82 \\
\hline Fruit circumference (cm) & 11.52 & 11.37 & 97.30 & 23.10 \\
\hline Number of fruits per plant & 21.78 & 21.64 & 98.73 & 44.29 \\
\hline Fruit weight (g) & 8.94 & 8.56 & 91.76 & 16.90 \\
\hline Yield per vine (kg) & 21.00 & 20.86 & 98.68 & 42.69 \\
\hline Yield (t/ha) & 21.04 & 20.89 & 98.57 & 42.73 \\
\hline
\end{tabular}

Table.3 Estimates of Phenotypic and Genotypic coefficient between different parts of characters in cucumber

\begin{tabular}{|c|l|c|c|c|c|c|c|c|c|}
\hline & & $\mathbf{X}_{\mathbf{1}}$ & $\mathbf{X}_{\mathbf{2}}$ & $\mathbf{\mathbf { X } _ { 3 }}$ & $\mathbf{X}_{\mathbf{4}}$ & $\mathbf{X}_{\mathbf{5}}$ & $\mathbf{X}_{\mathbf{6}}$ & $\mathbf{X}_{\mathbf{7}}$ & $\mathbf{X}_{\mathbf{8}}$ \\
\hline $\mathbf{X}_{\mathbf{1}}$ & $\mathbf{G}$ & 0.000 & -0.212 & 0.205 & 0.038 & -0.282 & 0.164 & 0.010 & -0.026 \\
\hline & $\mathbf{P}$ & 0.000 & -0.208 & 0.203 & 0.039 & -0.263 & 0.158 & 0.009 & -0.023 \\
\hline $\mathbf{X}_{\mathbf{2}}$ & $\mathbf{G}$ & & 0.000 & 0.111 & $-0.562^{* *}$ & -0.263 & -0.032 & $0.454^{*}$ & $0.505^{*}$ \\
\hline & $\mathbf{P}$ & & 0.000 & 0.111 & $-0.558^{* *}$ & -0.249 & -0.030 & $0.449 *$ & $0.496^{*}$ \\
\hline $\mathbf{X}_{\mathbf{3}}$ & $\mathbf{G}$ & & & 0.000 & 0.110 & 0.238 & 0.354 & -0.157 & -0.076 \\
\hline & $\mathbf{P}$ & & & 0.000 & 0.107 & 0.238 & 0.348 & -0.153 & -0.074 \\
\hline $\mathbf{X}_{\mathbf{4}}$ & $\mathbf{G}$ & & & & 0.000 & $0.439 *$ & 0.260 & $-0.934^{* *}$ & $-0.841^{* *}$ \\
\hline & $\mathbf{P}$ & & & & 0.000 & $0.422^{*}$ & 0.257 & $-0.926^{* *}$ & $-0.832^{* *}$ \\
\hline $\mathbf{X}_{\mathbf{5}}$ & $\mathbf{G}$ & & & & & 0.000 & 0.274 & $-0.421^{*}$ & -0.146 \\
\hline & $\mathbf{P}$ & & & & & 0.000 & 0.274 & $-0.405^{*}$ & -0.141 \\
\hline $\mathbf{X}_{\mathbf{6}}$ & $\mathbf{G}$ & & & & & & 0.000 & -0.219 & 0.052 \\
\hline & $\mathbf{P}$ & & & & & & 0.000 & -0.215 & 0.052 \\
\hline $\mathbf{X}_{\mathbf{7}}$ & $\mathbf{G}$ & & & & & & & 0.000 & $0.920^{*}$ \\
\hline & $\mathbf{P}$ & & & & & & & 0.000 & $0.908^{* *}$ \\
\hline $\mathbf{X}_{\mathbf{8}}$ & & & & & & & & & 0.000 \\
\hline & & & & & & & & 0.000 \\
\hline
\end{tabular}

$X_{1}$. Vine length $(\mathrm{cm}), X_{2}$ - Number of primary branches, $X_{3}$. Days to first female flowering, $X_{4}$ - Node at which first female flower appear, $X_{5}$. Fruit length $(\mathrm{cm}), X_{6}$. Fruit circumference $(\mathrm{cm}), X_{7}$. Number of fruits per plant, $X_{8}{ }^{-}$Yield per vine $(\mathrm{kg})$ 
Table.4 Direct (diagonal)) and indirect effect of different traits contributing to yield in cucumber (phenotypic level)

\begin{tabular}{|c|c|c|c|c|c|c|c|c|}
\hline Traits & $\mathbf{X}_{\mathbf{1}}$ & $\mathbf{X}_{\mathbf{2}}$ & $\mathbf{X}_{\mathbf{3}}$ & $\mathbf{X}_{\mathbf{4}}$ & $\mathbf{X}_{\mathbf{5}}$ & $\mathbf{X}_{\mathbf{6}}$ & $\mathbf{X}_{\mathbf{7}}$ & $\mathbf{X}_{\mathbf{8}}$ \\
\hline $\mathbf{X}_{\mathbf{1}}$ & $\mathbf{0 . 0 6 7}$ & -0.037 & -0.020 & 0.003 & -0.085 & 0.035 & 0.010 & $\mathbf{- 0 . 0 2 6}$ \\
\hline $\mathbf{X}_{\mathbf{2}}$ & -0.014 & $\mathbf{0 . 1 7 2}$ & -0.011 & -0.043 & -0.079 & -0.007 & 0.486 & $\mathbf{0 . 5 0 5}$ \\
\hline $\mathbf{X}_{\mathbf{3}}$ & 0.014 & 0.019 & $\mathbf{- 0 . 0 9 6}$ & 0.008 & 0.071 & 0.076 & -0.168 & $\mathbf{- 0 . 0 7 6}$ \\
\hline $\mathbf{X}_{\mathbf{4}}$ & 0.003 & -0.097 & -0.011 & $\mathbf{0 . 0 7 6}$ & 0.132 & 0.055 & -0.999 & $\mathbf{- 0 . 8 4 1}$ \\
\hline $\mathbf{X}_{\mathbf{5}}$ & -0.019 & -0.045 & -0.023 & 0.034 & $\mathbf{0 . 3 0 0}$ & 0.058 & -0.451 & $\mathbf{- 0 . 1 4 6}$ \\
\hline $\mathbf{X}_{\mathbf{6}}$ & 0.011 & -0.006 & -0.034 & 0.020 & 0.082 & $\mathbf{0 . 2 1 3}$ & -0.235 & $\mathbf{0 . 0 5 2}$ \\
\hline $\mathbf{X}_{\mathbf{7}}$ & 0.001 & 0.078 & 0.015 & -0.071 & -0.126 & -0.047 & $\mathbf{1 . 0 7 0}$ & $\mathbf{0 . 9 2 0}$ \\
\hline
\end{tabular}

The genotypic coefficient of variation does not offer full scope to estimate the variation that is heritable and, therefore, estimation of heritability become necessary. The magnitude of heritability ranged from 91.76 to $99.33 \%$. Maximum heritability was found for node at which first female flower appear followed by number of primary branches, number of fruits per plant, yield per plant and yield per hectare which showed that the variability in these characters would be effective. These findings are in accordance with those of Liu and Staub. The value of genetic advance as percentage of mean (genetic gain) ranged from 16.90to 54.55. High heritability coupled with high genetic gain in node at which first female flower appear, number of primary branches, number of fruits per plant and yield per vine indicated that these characters had additive gene effects and, therefore, these characters were more reliable for effective selection. In present investigation, yield/vine was found to be significantly and positively associated with number of primary branches and number of fruits per plant at genotypic and phenotypic level (Table 3). Number of fruits per plant also showed significant and positive association with number of primary branches at both levels. Fruit length was also found to be significantly and positively associated with node at which first female flower appear at both genotypic and phenotypic level. Number of fruits per plant recorded a significant negative genotypic and phenotypic correlation with node at which first female flower appear and fruit length wherein node at which first female flower appeared showed a significant and negative correlation with number of primary branches at both genotypic and phenotypic level. It is suggested that for effective selection for higher fruit yield per vine number of primary branches per plant, node at which first female flower appeared, number of fruits per plant and fruit length are the important characters. Similar result has also been reported by Rastogi et al., and Chen et al., in cucumber. In the present investigation, higher and positive direct effect (at phenotypic level) on fruit yield was exerted by number of fruits per plant followed by fruit length and fruit circumference. Number of primary branches per plant and node at which first female flower appeared also showed positive and significant correlation with fruit yield/plant (Table 4). This indicated that direct selection based on number of fruits/plant would result inappreciable improvement of fruit yield per vine. These findings are in agreement with Grebnsickov. From the above results, characters showing high range of variation, GCV and PCV, heritability and heritability combined with high genetic gain for number of primary branches per plant, node at which first female flower appeared, fruit length, fruit circumference, number of fruits per plant and fruit yield per vine could be exploited for improvement through selection. In present 
study, the characters like number of primary branches per plant, node at which first female flower appeared and number of fruits per plant showing positive significant correlation with fruit yield per vine had appreciable direct effects towards fruit yield and proved as important components of fruit yield. The selection based on these characters may result in development of high yielding genotypes.

\section{References}

Al-Jibouri, H.A., Muller, P.A. and Robinson, H.P.1958. Genotypic and environmental variances and covariances in a upland crop of interspecific origin. Agron. J. 30: 633-36.

Burton, G.W. and De Vane, E.W. 1953. Estimating heritability in tall fescue (Festucaar undinacea) from replicated clonal material. Agron. J. 45:478-81.

Chen, Xuehao; Caopeisheng and $\mathrm{Xu}$, Quiany1994. Genetic correlation and path coefficient analysis of yield components in cucumber in Beijing, China. Adv. Hort.: 249-51.

Dewey, D.R. and Lu, K.H. (1959). A correlation and path coefficient analysis of component of crested wheat grass seed production. Agron. J.51: 515-18.

Grebensickov, IGORI. 1979. Notes on cucurbits for estimation of the influence of plant length and fruit number upon fruit yield/plant in cucurbits by means of path analysis. Kultui Pflanzen,
27:197-206.

Johnson, H.W., Robinson, H.F. and Comstock, R.E. 1955. Estimates of genetic and environmental variability in soybean. Agron. J. 47: 314-18.

Joshi, S., Singh, M.C., Singh, B. and Visnoi, A.K. (1981). Genotypic and phenotypic variability in cucumber (Cucumis sativus L.). Veg. Sci. 8:114-19.

Lui, J.S. and Staub, J.E. (1999). Analysis of genetic correlation for several major characters of botanical varieties and cultivars in cucumber. China Vegetable 5: $16-19$.

Panse, V.G. and Sukhatme, P.V. 1967. Statistical methods for Agricultural Workers. Indian Council of Agricultural Research, New Delhi.

Rastogi, K.B. Arya, Deepak and Deep, A. 1990. Anote on inter-relationship between yield and important plant characters of cucumber (Cucumis sativus L.). Veg. Sci. 17: 102-04.

Yawalkar KS. Vegetable Crops of India, Agri Horticultural Publishing House, Nagpur, 1985. Saikia J, Shadeque A, Bora GC. Genetic studies in cucumber. Haryana Journal of Horticultural Science. 1995; 24(1):73-76.

Tatlioglu, T. 1993. Cucumber (Cucumis sativus L.). In: Genetic Improvement of Vegetable Crops. (Kalloo, G. and Beorgh, B.O., Eds). Pergamon Press, Oxford, pp. 197-233.

\section{How to cite this article:}

Manivannan, M. I., R. Arulmozhiyan and Suresh, R. 2020. Genetic Analysis for Quantitative Traits in Cucumber [Cucumis sativus (L.)]. Int.J.Curr.Microbiol.App.Sci. 9(12): 1547-1552. doi: https://doi.org/10.20546/ijcmas.2020.912.183 